\title{
Export diversification in conditions of globalization: a comparative analysis of Azerbaijan, Kazakhstan and Russia
}

\author{
Lala Hamidova ${ }^{1, *}$ \\ ${ }^{1}$ Azerbaijan State University of Economics, Department of Economics, Istiglaliyyat, 6, Baku AZ1001, \\ Azerbaijan
}

\begin{abstract}
Research background: The Caspian region with rich hydrocarbons and a favorable location has always been in the attention of researchers. Large oil reserves of the Caspian countries - Azerbaijan, Russia and Kazakhstan have become an object of interest for world business. These countries have much in common: they were part of a Soviet Union for 70 years. However, during the period of market reforms, the Caspian countries turned out to be uncompetitive in both domestic and foreign commodity markets, the commodity structure of exports was significantly degraded, and its raw orientation increased.

Purpose of the article: The main objective of the study is to reveal the problems of diversification of commodity exports of the Caspian countries, a comparative analysis of the structure of their commodity exports in the context of the development of the globalization of the world economy and the intensification of international competition.

Methods: We used the methods of comparative analysis of the export structure of Azerbaijan, Kazakhstan and Russia by main product groups, by top-five goods. To determine the level of diversification and export concentration, the Herfindahl-Hirschman index and the export concentration index were used.

Findings \& Value added: The calculations of the Herfindahl-Hirschman index show a low level of export diversification in these countries, especially in Azerbaijan. The export concentration index showed that the top-five of exported goods are mainly natural raw materials. In the non-oil sector, in all three countries, unproductive and not-tradable sectors: construction, trade and transport prevail.
\end{abstract}

Keywords: export diversification; Caspian region; non-oil sector; governance effectiveness

JEL Classification: $O 13 ; 043 ; P 5$

\footnotetext{
*Corresponding author: lala hamidova@unec.edu.az
} 


\section{Introduction}

Today, the Caspian region, due to its geo-economic advantages and geo-economic position, rich in energy resources, is a transport and communication corridor between Europe and Asia, turning into a region of transnational activity. The Caspian countries - especially Russia, Kazakhstan and Azerbaijan - are beginning to play a prominent role in the global economy. In the context of globalization, the growth of the gross domestic product in these countries is accompanied by the strengthening of their integration into the world economy, into the system of international economic relations. And if in the first years of independence they did not have competitive products and offered hydrocarbon resources on foreign markets, then in subsequent years conditions appeared for the export of various goods. The diversification of exports carried out by the countries will increase export revenues and reduce the risks of dependence of the national economy on the export of one resource [1]. The more effective the processes of organizing foreign economic activity and using the export potential, the more successfully the national economies of the countries will develop [2]. At present, oil and gas still dominate in the structure of exports of the studied countries, which indicates a one-sided orientation of exports [3]. However, the Caspian countries have all the conditions for export diversification.

The aim of this study is to reveal the complex merchandise exports of the Caspian countries to diversify problems, determining the level of export diversification, the comparison of commodity structure of export of Azerbaijan, Kazakhstan and Russia in the context of globalization of the world economy. These problems have been considered by a number of scientists over the years. Export diversification issues were addressed by [4-9]. Summarizing research in this direction, we note that exports are more diversified when bilateral trade costs are relatively low. Of great interest are the findings of Makhlouf, Kellard and Vinogradov, who in a group study of 116 countries over 35 years showed that trade openness is associated with both specialization and diversification [10]. Among developing countries, their sample noted that autocratic openness is associated with specialization, and democratic openness is associated with export diversification.

Resource-rich countries experience low levels of economic diversification, as resources dominate exports and government revenues [11, 12]. Institutional factors that enable countries to effectively manage resource wealth are important for successful diversification [13]. To determine the level of efficiency in the management of oil and gas resources, the RGI index was used. The RGI is based on the assumption that effective natural resource management is essential for the successful development of countries with abundant oil, gas and mineral resources.

\section{Methods}

The export of a country is one of the main indicators of its economy, which partially determines its specialization in the world division of labor and shows its importance for both partners and competitors [14]. The export dynamics of the Caspian countries is approximately identical: in 1990-1999, exports were just getting better and the countries began to get out of the crisis caused by the collapse of the Soviet Union; 2000-2004 saw a rapid growth in production and a rapid rise in oil prices; from 2005 to the present, exports have acquired modern features and have stabilized. Taking into account this fact, 2005-2018 were taken for the analyzed period.

To assess the level of export diversification, a comparative analysis of the export structure of Azerbaijan, Kazakhstan and Russia was carried out by major commodity groups; the Herfindahl - Hirschmann Index (HHI) and the Concentration Ratio (CR) were calculated.

$\mathrm{HHI}$ is defined as the sum of the squares of the export share of commodity groups. It is 
measured from 0 to 1 . The HHI indicator is closer to 1 , when a country exports mainly one good or service; it means a high concentration, and therefore a low diversification of exports.

The Concentration Ratio is calculated as the sum of the export shares of the largest export categories. It is measured from 0 to $100 \%$. If the CR value is closer to $100 \%$, then this means a high concentration of several main types of goods in comparison with all exports. Typically CR (4), CR (6), or CR (8) are used [15]. This means calculating the level of concentration, respectively, for four, six or eight main types of exported goods. In this study, the CR indicator (4) was taken as the basis. With CR (4)>70\%, exports are considered highly concentrated, i.e. undiversified; at $45 \%<\mathrm{CR}(4) \leq 70 \%$ - moderately concentrated export; with CR (4) $\leq 45 \%$ - low-concentration export.

One of the indicators characterizing the effectiveness of state management of natural resources is a Resource Governance Index (RGI), calculated by the Natural Resource Management Institute (NRGI). The Resource Governance Index assesses the quality of natural resource management in 81 countries that produce, among other raw materials, $82 \%$ of the world's oil, $78 \%$ of the world's gas and $72 \%$ of copper. RGI consists of three components: 1. Value realization, 2. Revenue management, 3. Enabling environment. Based on these components, a general index (Composite) is formed. Using the RGI index, each country is assigned a quantitative sum of points that allows the country to be included in one of four groups in terms of management efficiency: satisfactory (71-100 points), partially satisfactory (51-70 points), weak (41-50) and unsatisfactory (0-40 points) [16].

\section{Results and Discussions}

\subsection{Export Diversification Index}

As the data in Table 1, the leading export products in all three countries are mineral products. If the share of mineral products in the structure of Russian exports was $60-70 \%$ in $2005-2018$, in Kazakhstan - 65-80\% depending on the year, then in Azerbaijan the share of mineral products was about $90 \%$. A high share of oil and gas in the exports of these countries was observed until 2015, which was due to high world oil prices. After 2015, the volumes of exports of fuel and energy resources in Kazakhstan and Russia have decreased, but in Azerbaijan the share of mineral products again began to rise: in 2018 the share of crude oil and gas in the country's exports amounted to $91.9 \%$. In addition to fuel and energy products, a high share of metals prevailed in the exports of Kazakhstan and Russia - in 2018 about $14.7 \%$ and $10.4 \%$, respectively.

Table 1. Structure of exports by main commodity groups [17-19]

\begin{tabular}{|c|c|c|c|c|c|c|}
\hline & 2005 & 2010 & 2015 & 2016 & 2017 & 2018 \\
\hline \multicolumn{7}{|c|}{ Products of animal and plant origin (including finished food products) } \\
\hline Azerbaijan & 7,6 & 2,8 & 6,0 & 3,9 & 4,3 & 3,7 \\
\hline Kazakhstan & 2,3 & 3,3 & 4,6 & 5,9 & 5,0 & 5,0 \\
\hline Russia & 1,9 & 2,2 & 4,7 & 6,0 & 5,8 & 5,6 \\
\hline \multicolumn{7}{|c|}{ Mineral products } \\
\hline Azerbaijan & 76,8 & 94,2 & 88,0 & 91,4 & 90,8 & 92,1 \\
\hline Kazakhstan & 73,8 & 74,8 & 71,3 & 65,0 & 68,5 & 74,5 \\
\hline Russia & 64,8 & 68,5 & 63,8 & 59,2 & 60,4 & 64,9 \\
\hline \multicolumn{7}{|c|}{ Chemical products (including rubbers and plastics) } \\
\hline Azerbaijan & 4,7 & 0,5 & 1,5 & 1,1 & 1,2 & 1,0 \\
\hline Kazakhstan & 3,3 & 5,1 & 7,3 & 7,2 & 5,1 & 4,2 \\
\hline Russia & 6,0 & 6,2 & 7,4 & 7,3 & 6,7 & 6,3 \\
\hline
\end{tabular}




\begin{tabular}{|c|c|c|c|c|c|c|}
\hline \multicolumn{8}{|c|}{ Wood, pulp and paper products } \\
\hline Azerbaijan & 1,4 & 0,2 & 0,3 & 0,3 & 0,5 & 0,1 \\
\hline Kazakhstan & 0,1 & 0,0 & 0,0 & 0,7 & 0,1 & 0,1 \\
\hline Russia & 3,4 & 2,4 & 2,9 & 3,4 & 3,3 & 3,1 \\
\hline \multicolumn{7}{|c|}{ Leather products } \\
\hline Azerbaijan & 0,1 & 0,1 & 0,1 & 0,1 & 0,1 & 0,1 \\
\hline Kazakhstan & 0,9 & 0,0 & 0,1 & 0,1 & 0,0 & 0,0 \\
\hline Russia & 0,1 & 0,1 & 0,1 & 0,1 & 0,1 & 0,1 \\
\hline \multicolumn{7}{|c|}{ Textiles, footwear, haberdashery } \\
\hline Azerbaijan & 1,3 & 0,2 & 0,3 & 0,3 & 0,5 & 0,7 \\
\hline Kazakhstan & 0,8 & 0,2 & 0,4 & 0,4 & 0,1 & 0,3 \\
\hline Russia & 0,4 & 0,2 & 0,3 & 0,3 & 0,3 & 0,3 \\
\hline \multicolumn{7}{|c|}{ Low-value stones and metals } \\
\hline Azerbaijan & 2,3 & 1,0 & 1,7 & 2,1 & 2,2 & 1,9 \\
\hline Kazakhstan & 17,3 & 15,5 & 13,1 & 16,8 & 18,1 & 14,7 \\
\hline Russia & 16,8 & 12,7 & 11,9 & 13,2 & 13,5 & 10,4 \\
\hline \multicolumn{7}{|c|}{ Machinery, equipment, vehicle } \\
\hline Azerbaijan & 5,8 & 1,0 & 0,5 & 0,8 & 0,4 & 0,4 \\
\hline Kazakhstan & 1,3 & 0,7 & 1,4 & 2,0 & 1,4 & 1,1 \\
\hline Russia & 5,6 & 5,4 & 7,4 & 8,6 & 6,0 & 6,5 \\
\hline Azerbaijan & 0,0 & 0,0 & 1,6 & 0,0 & 0,0 & 0,0 \\
\hline Kazakhstan & 0,0 & 0,4 & 1,8 & 1,8 & 1,4 & 0,1 \\
\hline Russia & 1,0 & - & 1,5 & 1,9 & 1,9 & 1,8 \\
\hline
\end{tabular}

The structure of exports by major commodity groups for 2005-2018 points to a more specialized export dominated by mineral products, of which most are crude oil and gas. Calculations of the Herfindahl-Hirschman index show a low level of export diversification, especially in Azerbaijan (Figure 1). The best position in Russia - HHI was 0.4-0.5 over the analyzed period. In Kazakhstan the level of export diversification is $0.5-0.6$, and in Azerbaijan it is $0.8-0.85$.

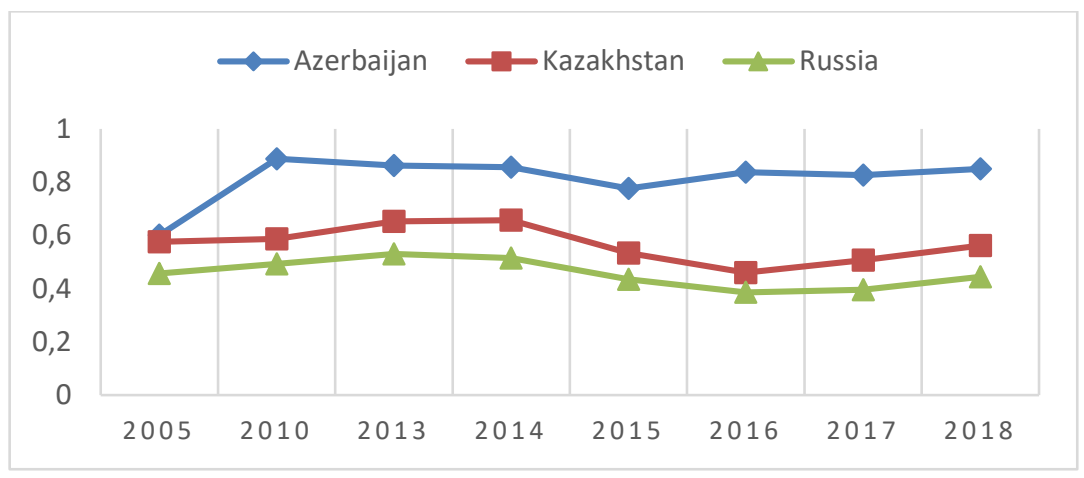

Fig. 1. HHI: export diversification.

\subsection{The Concentration Ratio (CR 4)}

Pictures 2-4 show the structure of exports of Azerbaijan, Kazakhstan and Russia by four main types of goods for 2005-2018. As can be seen from Figure 2, crude oil dominates in the structure of Azerbaijan's exports - over $80 \%$ of all exports and natural gas - $4-11 \%$ of all exports in different years. The four main types of exported goods are mainly raw materials: in addition to crude oil and natural gas, these are raw, unprocessed fruits, as well as crude oil 
products. The situation in Kazakhstan is better: crude oil and oil products in total exports account for 53-68\% depending on the year (Figure 3). Of the 4 most important export commodities, only pure raw materials are crude oil, and the rest are partially refined products. These are ferroalloys, refined copper and inorganic chemicals. The share of crude oil in Russian exports was $26-34 \%$ in $2005-2018$, and natural gas was about $11-13 \%$. $14-23 \%$ of exports fell on petroleum products (Figure 4).

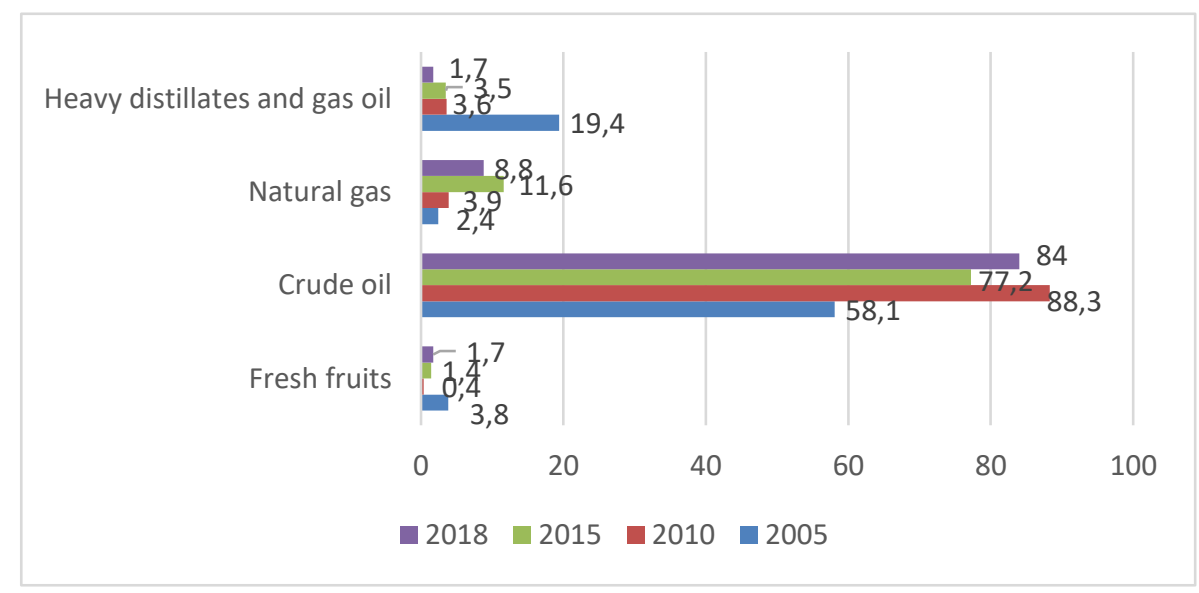

Fig. 2. Azerbaijan: structure of exports by 4 main types of goods (in \%)

Inorganic chemistry products

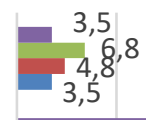

Crude oil and oil products

Refined copper and alloys

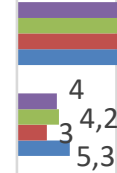

Ferroalloys

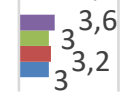

$0 \quad 10$

1020

30

$2018-2015$

2010

2005

Fig. 3. Kazakhstan: structure of exports by 4 main types of goods (in \%) 


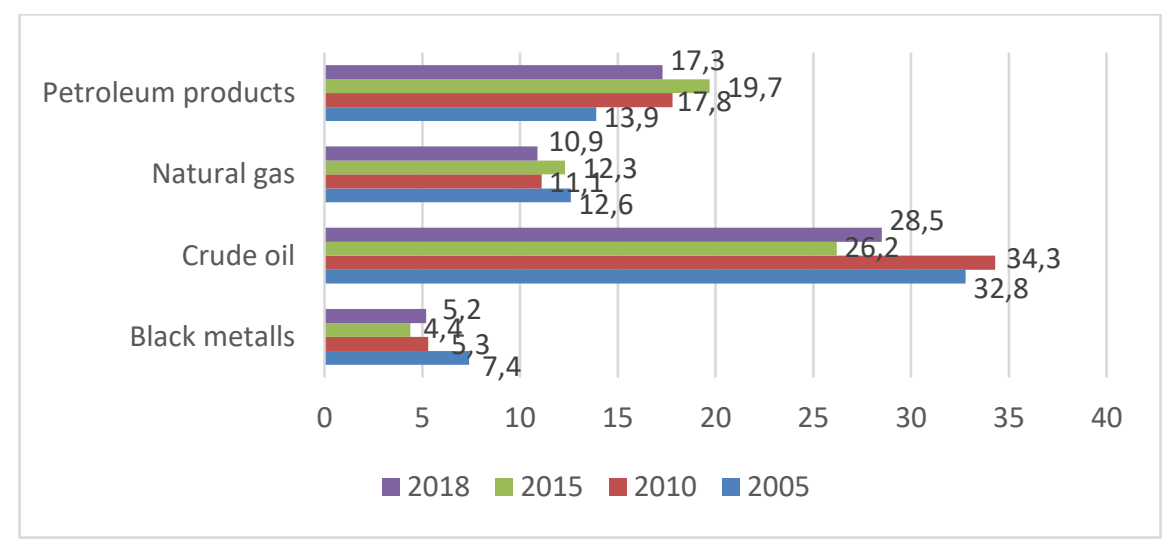

Fig. 4. Kazakhstan: structure of exports by 4 main types of goods (in \%)

As can be seen from Figure 5, the export concentration index CR (4) for the analyzed period in Azerbaijan was 84.1-97.2. This means that the four most important export goods for countries account for 84-97\% of all exports. As can be seen from Figure 5, in Kazakhstan and Russia, the export concentration index is lower: it was approximately 71-79 and 62-72, respectively.

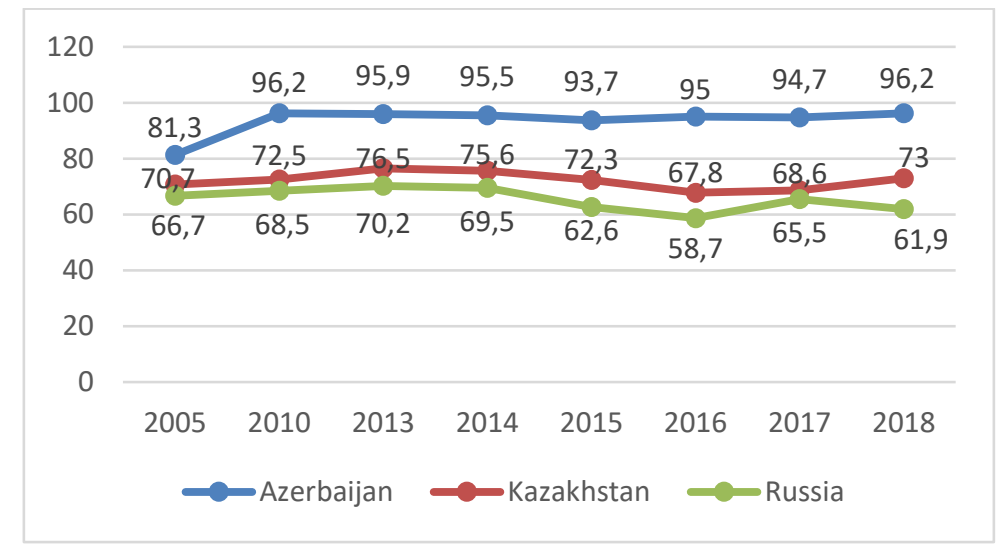

Fig. 5. CR (4): Export concentration index based on the four main export goods

\subsection{Resource Governance Index}

Figure 6, reflecting the RGI indicator for Azerbaijan, Kazakhstan and Russia, shows that Kazakhstan's position in natural resource management is slightly higher: the country received 56 points out of 100 and ranks 25th among 89 countries, while Azerbaijan, with 47 points, takes 47 th place, and Russia with 45 points - 50th place. 


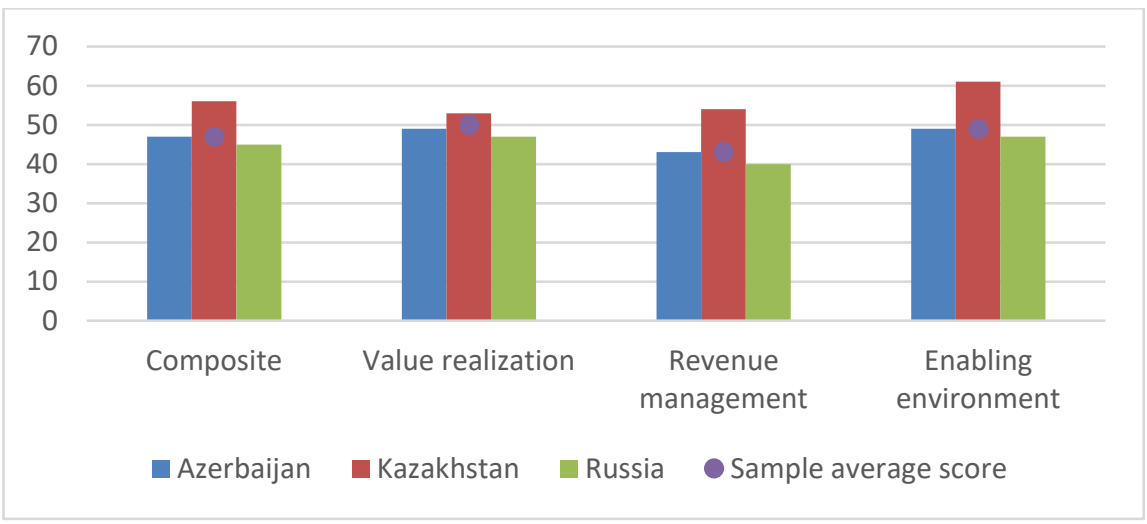

Fig. 6. RGI: Azerbaijan, Kazakhstan, Russia (Oil \& Gas) [16]

\section{Conclusions}

Analysis of the level of diversification in Azerbaijan, Kazakhstan and Russia raises concerns about the sustainability of long-term economic growth in these countries.

First, based on the export concentration index, it can be seen that the "four" of exported goods are mainly natural resources. In Azerbaijan, 84\% of exports in 2018 came from the export of crude oil. Although Russian exports look less concentrated, $56.7 \%$ of exports go to the oil and gas sector (2018 data). Kazakhstan has a high share of non-primary products in total exports, consisting mainly of unprocessed ferroalloys, steel, ores and copper. However, the sectors are located in the lower ring of the value chain and are not able to generate high added value.

Second, the development of the non-oil sector in all three countries is dominated by nonproductive and not-tradable sectors: construction, trade and transport. The peculiarity of nottradable sectors is that their development is carried out at the expense of public investments and depends on the level of consumption and the capabilities of the population [20]. In other words, in the event of an economic downturn, when the income of the population deteriorates, the government will experience a large financial deficit [21].

To overcome the one-sidedness of exports, investments are needed, primarily foreign ones. The globalization of production and capital are interrelated: according to a study by the World Bank, the role of foreign investment in export growth is very large [22]. Transnational corporations invest in every link of their production chain, which is a priori designed for export: in the post-industrial age, those who integrate into global production chains win [23]. In addition to increasing tax revenues to the budget and creating jobs, goods that withstand competition in the global market help reduce oil dependence; make the economy more resilient to surges in energy prices [24].

The RGI analysis results for Azerbaijan, Kazakhstan and Russia show that these countries are ineffectively generating revenues from natural resources. Low RGI indicate that when oil and gas revenues go to the state budget, these revenues are often not spent for the benefit of society. The Caspian countries received relatively low scores due to the poor state of national governance, in which corruption, nd restrictions on civil and political freedom plays a key role. State-owned companies, wealth funds and resource revenue transfers are important in natural resource management. Therefore, proper management of natural resources is essential for the successful development of countries rich in oil, gas and minerals. 


\section{References}

1. dePineres, S.A.G., Ferrantino, M. (1997). Export diversification and structural dynamics in the growth process: The case of Chile. Journal of Development Economics, 52(2), 375-391.

2. Balavac, M., Pugh, G. (2016). The link between trade openness, export diversification, institutions and output volatility in transition countries. Economic Systems, 40(2), 273287.

3. Hampel-Milagrosa, A., Haydarov, A., Anderson, K., Sibal, J., Ginting, E. (2020). Azerbaijan: Moving toward more diversified, resilient, and inclusive development. Asian Development Bank, 216.

4. Ayobola, Ch., Ekundayo, M., Muibi, S. (2018). Resource Endowment and Export Diversification: Implications for Growth in Nigeria. Studies in Business and Economics, 13(1), 29-40.

5. Gozgor, G., Can, M. (2017). Causal Linkages among the Product Diversification of Exports, Economic Globalization and Economic Growth. Review of Development Economics, 21(3), 888-908.

6. Mau, K. (2016). Export diversification and income differences reconsidered: the extensive product margin in theory and application. Review of World Economics, (Weltwirtschaftliches Archiv), Springer; Institut für Weltwirtschaft (Kiel Institute for the World Economy), 152(2), 351-381.

7. Naude, W., Rossouw, R. (2011). Export diversification and economic performance: evidence from Brazil, China, India, and South Africa. Economic Change and Restructuring, 44(1-2), 99-134.

8. Cirera, X., Marin, A., Markwald, R. (2015). Explaining export diversification through firm innovation decisions: The case of Brazil. Research Policy, 44(10), 1962-1973.

9. Aditya, A., Acharyya, R. (2015). Trade liberalization and export diversification. International Review of Economics \& Finance, 39(C), 390-410.

10. Makhlouf, Y., Kellard, N., Vinogradov, D. (2015). Trade openness, export diversification, and political regimes. Economics Letters, 136(C), 25-27.

11. Ross, M.L. (2017). What Do We Know About Economic Diversification in OilProducing Countries? EEG State-of-Knowledge Paper Series, 5(2), 1-44.

12. Bahar, D., Santos, M.A.(2018). One more resource curse: Dutch disease and export concentration. Journal of Development Economics, 132, 102-114.

13. Gelb, A. (2010). Economic Diversification in Resource Rich Countries. Center for Global Development, IMF, 1-23.

14. Cos, P., Colonn, A., Cabases, A. (2019). Geographic export diversification: Determinants and their link with export performance. Thunderbird International Business Review, 61(2), 397-411.

15. Meilak, C. (2008). Measuring export concentration: the implications for small states. Bank of Valletta Review, 37, 35-48.

16. Resource Governance Index. (2017). Natural Resource Governance Institute. Retrieved from : https://api.resourcegovernanceindex.org/system/documents/documents/000/000 /046/original/2017_Resource_Governance_Index.pdf?1498599435

17. The Foreign Trade of Azerbaijan. (2020). Statistical publication. State Statistical Committee of Azerbaijan Republic. Retrieved from : https://www.stat.gov.az/source/trade/ 
18. The Foreign Trade of Kazakhstan Republic. (2019). State Statistical Committee of Kazakhstan Republic. Retrieved from : https://stat.gov.kz/edition/publication/collection

19. Integrated foreign economic information portal. (2019). Integrated foreign economic information portal. Ministry of economic development of the Russian Federation. Retrieved from : http://www.ved.gov.ru/monitoring/foreign_trade_statistics/ basic_goods_export/

20. Caselli, F., Koren, M., Lisicky, M. Tenreyro, S. (2020). Diversification through trade. Quarterly Journal of Economics, 135(1), 449-502.

21. Bayramov, V., Orujova, L. (2017). Volatility, Diversification and Oil Shock in Resource-Rich Turkic Countries: Avenues for Recovery. Journal of Social Sciences of the Turkic World, BILIG, 83, 303-329.

22. World Bank Group (2019). Weaker Global Outlook Sharpens Focus on Domestic Reforms. Russia Economic Report, World Bank, 42, 9-64.

23. Banga, R. (2006). The export-diversifying impact of Japanese and US foreign direct investments in the Indian manufacturing sector. Journal of International Business Studies, 37(4), 558-568.

24. Lashitew, A.A., Ross, M.L., Werker, E. (2020). What drives successful economic diversification in resource-rich countries? The World Bank Research Observer, 3-38. 